\title{
Campus Food Provision as Radical Pedagogy? Following Students on the Path to Equitable Food Systems
}

\section{OPEN ACCESS}

Edited by:

Nicholas R. Jordan, Independent Researcher, St. Paul,

United States

Reviewed by:

Jacqueline Ignatova, Appalachian State University,

United States

Amanda Green,

Eastern Kentucky University,

United States

${ }^{*}$ Correspondence:

Michael Classens

michael.classens@utoronto.ca

tThese authors have contributed equally to this work and share second authorship

FThese authors have contributed equally to this work and share third authorship

Specialty section:

This article was submitted to Social Movements, Institutions and

Governance,

a section of the journal Frontiers in Sustainable Food Systems

Received: 30 July 2021 Accepted: 05 November 2021 Published: 30 November 2021

Citation: Classens M, Adam K, Crouthers SD, Sheward $N$ and Lee $R$ (2021) Campus Food Provision as Radical Pedagogy? Following Students on the Path to Equitable Food Systems. Front. Sustain. Food Syst. 5:750522. doi: 10.3389/fsufs.2021.750522

\author{
Michael Classens ${ }^{1 *}$, Kaitlyn Adam ${ }^{2 \dagger}$, Sara Deris Crouthers ${ }^{3 \dagger}$, Natasha Sheward ${ }^{2 \neq}$ and \\ Rachel Lee ${ }^{2 f}$ \\ ${ }^{1}$ School of the Environment, University of Toronto, Toronto, ON, Canada, ${ }^{2}$ School of the Environment, Trent University, \\ Peterborough, ON, Canada, ${ }^{3}$ Faculty of Education, York University, Toronto, ON, Canada
}

On campuses across North America, students are actively prefiguring alternatives to the fundamental inequities and unsustainability of the capital-intensive, industrialized food system. While rarely recognized as such, these Campus Food System Alternatives (CFSA) are intensely pedagogical spaces, and often-importantly -are student led and directed. We make the case that CFSA are sites for a "pedagogy of radical hope" that (a) centre student agency, (b) through informal and prefigurative learning. So far these spaces have received scant scholarly attention, though inasmuch as they constitute pathways toward more equitable and sustainable food systems, while informing liberatory pedagogical practice, we argue that it is high time for CFSA to be taken seriously.

Keywords: critical food systems education, campus food systems, campus food initiatives, informal learning, social and ecological change

\section{INTRODUCTION: FROM SCHOOLS OF DEATH TO LIBERATORY LEARNING}

In his recent forceful condemnation and reimagination of higher education, Gannon (2020) invokes Nikolai Frederik Severin Grundtvig, one of the founders of the Danish folk school movement. Writing in the mid-19th Century, Grundtvig castigates the educational orthodoxy of his time and place as an elitist pursuit that simply reproduced conventional power relations. Grundtvig insisted that these "schools of death" (quoted in Gannon, 2020, p. 11) were overly fixated on haughty (and irrelevant) scholarship, and he called for a new paradigm-"schools for life"-that were inclusive, applied, and focused on teaching and learning for civic engagement. At roughly the same time in the United States, Black leaders including Booker T. Washington, George Washington Carver and W. E. B. Du Bois were prefiguring new worlds at the intersection of agriculture and Black liberation through the founding of Tuskegee University (see White, 2018). Within this context, agriculture and agricultural education were framed as radical, as resistance, and as liberatory.

As underscored elsewhere (including in this collection), the stakes for food systems transformation could not be higher. The fundamental social inequities and ecological devastation wrought by the contemporary, capital-intensive food system are destabilizing the prospects for planetary survival (Holt-Gimenez and Shattuck, 2011; Altieri and Nicholls, 2020). Within this firmament, (re)education is an essential focal point and, like Grundtvig, Washington, Carver, $\mathrm{Du}$ Bois and others have observed, an essential element in food systems and broader socioecological transformation. 
TABLE 1 | Categorization schema for CFSA.

\begin{tabular}{|c|c|}
\hline Dimension & Exemplars \\
\hline $\begin{array}{l}\text { Promote sustainable production } \\
\text { (agroecological, organic, local, } \\
\text { etc). }\end{array}$ & $\begin{array}{l}\text { - UW Farm Market (University of Waterloo) } \\
\text { is a student-run market featuring 100\% } \\
\text { local and sustainably-sourced products. } \\
\text { - The Tea Room (Queen's University) is } \\
\text { a student-run café that sources socially } \\
\text { just and ecologically sound products. } \\
\text { - Dig In! Campus Agricultural Group } \\
\text { (University of Toronto) is a network } \\
\text { organization meant to support and } \\
\text { empower sustainable, small-scale food } \\
\text { production on campus. }\end{array}$ \\
\hline $\begin{array}{l}\text { Provide education (focused on } \\
\text { social and environmental justce) }\end{array}$ & $\begin{array}{l}\text { - Caffiends (University of Toronto) is a } \\
\text { student-run cafe that educates on social } \\
\text { and environmental justice. } \\
\text { - BIPOC Growing Collective (Trent } \\
\text { University), is a production collective } \\
\text { informed by abolitionist and decolonizing } \\
\text { practice, dedicated to reviving ancestral } \\
\text { and cultural practices with respect to } \\
\text { land and food. } \\
\text { - The Trent Apiary (Trent University), is a } \\
\text { student-run apiary dedicated to } \\
\text { educating about bees and their ecology. }\end{array}$ \\
\hline $\begin{array}{l}\text { Foster inclusive community and } \\
\text { student leadership }\end{array}$ & $\begin{array}{l}\text { - The People's Potato (Concordia } \\
\text { University) serves free meals to students, } \\
\text { staff and faculty and provides accessible } \\
\text { anti-oppressive community space. } \\
\text { - Embark Learning Garden (University of } \\
\text { Victoria) seeks to create just and } \\
\text { equitable growing spaces on campus } \\
\text { rooted in food justice and climate equity. }\end{array}$ \\
\hline Support student food security & $\begin{array}{l}\text { - People's Republic of Delicious (University } \\
\text { of Ottawa) is a student collective that } \\
\text { rescues blemished/nearly expired food } \\
\text { and serves it for free. } \\
\text { - The Hive Café Solidarity Co-op } \\
\text { (Concordia University) is a student- } \\
\text { run café meant to provide students } \\
\text { with affordable, socially-just and } \\
\text { ecologically-sound food. } \\
\text { - King's Galley (University of King's } \\
\text { College) is a student-run canteen that } \\
\text { offers ethically-sourced, and affordable } \\
\text { food to students. } \\
\text { - IGNITE Soup Bar (Humber College) is a } \\
\text { student union-operated, } \\
\text { pay-what-you-can soup bar. }\end{array}$ \\
\hline
\end{tabular}

In this short perspective piece, we theorize Campus Food System Alternatives (CFSA) - that is, initiatives that exist as counter-points to conventional campus food services-as crucially important pedagogical spaces from which to wage food systems transformation. In developing this perspective further, we briefly (a) situate how we think about pedagogy, (b) provide a typological sketch of CFSA by summarizing some key themes emerging from our ongoing work, and by way of conclusion, (c) offer some recommendations related to supporting CFSA through future research and action.

The paper draws empirically on two interrelated studies. The first includes a detailed scan of Canadian postsecondary institution websites for mention of various campus farms in Canada $(N=\sim 80)$ and a Canada-wide survey of students $(N=65)$ engaged in campus farms across Canada, worked conducted by the first author and a research assistant (see Classens and Burton, in press). The second study includes an initial Internet scan for mention of various food initiatives, beyond farms, on campuses across Canada $\left(N=\sim 72^{1}\right)$ which led us to postsecondary institution websites from across the country, social media pages, food initiative websites ${ }^{2}$, and online news articles. We then conducted interviews with 24 leaders of initiatives identified in this latter scan. This work was conducted by the first, second, fourth and fifth authors. This paper also draws on our respective embodied experiences working within CFSA as students, advocates and faculty, and is inspired by the student leadership and innovation that creates such transformative potential within CFSA.

\section{ON (CRITICAL) PEDAGOGY}

When we conceptualize pedagogy, we frequently envision a space with neat rows of desks and one singular expert educator at the head of the class, conveying information on a discrete subject to an uneducated audience. The banking method of education, which Freire (1968) so fiercely critiques, whereby education is reduced to a single expert filling the empty minds of pupils, is so pervasive in contemporary postsecondary institutions that the opportunities within non-traditional, informal pedagogical spaces such as CFSA often go overlooked. Institutionally endorsed learning, such as lecturing, is often administered in temporal and geographic spaces that have been so designated (i.e., a school classroom or a university lecture hall). This dynamic can even be reproduced within CFSAs, for example when planned experiential learning activities within the context of a class (such as a class trip to a campus farm) are understood as the pedagogical limits of these spaces.

Following the work of Freire (1968), Hooks (1994), and others, we conceive of pedagogical spaces as any temporal or geographic space that functions to bring collaborators together in a shared endeavor where learning will inevitably happen. Learning can be formal and scheduled, but is also-importantly-informal and unexpected (Crouthers, 2021). This approach understands that contextual and experiential education is often the most impactful (Carrier, 2009; Chawla, 2015). Although students may initially gather through a CFSA for a singular purpose, such as the need for food access or a desire to gain practical

\footnotetext{
${ }^{1}$ We are reporting on preliminary and ongoing work. As such, we have yet to determine if all of the identified food initiatives from our initial Internet scan are still active. We note here that there are an additional 57 initiatives for which we found some online presence, though we have yet to verify whether these projects are currently active. Given the particular disruption of COVID-19, and the more general issue of continuity with student-run organizations, it is likely very difficult to arrive at a definitive, permanent list of CFSA. Some social media pages have not been updated in several years, some social media pages or websites were no longer in service, and some of their email addresses bounced when we contacted them for interviews. Future dispatches will report on refined results and a firmer typology as we continue the process of confirming, and better understanding, active initiatives. ${ }^{2}$ See Table 1 below for examples of initiatives.
} 
farming skills, participants experience a much wider range of learning through interactions among members, between CFSA members and host institutions, external community members and allied organizations.

A radical pedagogical approach does not begin with a set curriculum; rather, it relies on inviting and platforming the exchange of embodied funds of knowledge (Gonzalez et al., 2005; Cruz et al., 2018). Funds of knowledge is a "community-oriented pedagogy" (Moll, 2019, p. 131), grounded in the idea that community members (particularly traditionally marginalized community members) have developed a wealth of lived experience, and produced and acquired knowledge through "the living of their lives" (Moll, 2019, p. 131). These funds of knowledge represent unlimited rich and diverse potential curricula. Each community member is a co-creator of knowledge, both a teacher and a learner. It is through these pedagogical spaces that hope, empowerment and resistance may be developed. A radical embodied pedagogy allows collaborators to envision systems beyond our current realities; it is the "belief in possibilities...the unlimited potential of practical problem solving and the transmission of knowledge and values" (Battiste, 2013, p. 175).

\section{CAMPUS FOOD SYSTEM ALTERNATIVES}

On-campus learning environments, outside the classroom, have been the subject of pedagogical inquiry for quite some time. In particular, wellness centres (Mirwaldt, 2010) and residences (Vetere, 2010) have been demonstrated as formative sites of learning through informal pedagogical experiences (see also Keeling, 2006; Buddel, 2015). Food systems scholars have also demonstrated the value of discrete spaces on-campus, beyond the classroom, that promote critical food systems learning. RobertsStahlbrand (2020), for example, makes a compelling case that informal food systems learning is an inherent-and crucialelement of the dining hall experience. Campus food growing spaces $^{3}$ have also been identified by scholars as important sites of food systems education. In the United States, campus food growing spaces ballooned from just 23 in 1992 to an estimated 300 by 2016 (LaCharite, 2016, p. 521). In Canada, meanwhile, research suggests that there are upwards of 80 postsecondary campuses with some kind of campus food growing space (Classens and Burton, in press).

By and large, these campus food growing spaces stand as a counterpoint to the conventional agricultural system and associated education paradigm (Barlett, 2011; Sayre and Clark, 2011). These spaces provide opportunities for experiential and informal learning through social organizing and agroecological experimentation - they serve as "insulated spaces for the growth of new nodes, actors and institutions in the food chain" (Barlett,

\footnotetext{
${ }^{3}$ We use "campus food growing space" here to denote a variety of configurations, from small box planters (seen on many campuses) to farms of several dozen acres (such as at the University of British Columbia, or Trent University). There is, as yet, no exhaustive typology of these kinds of spaces in Canada (see LaCharite, 2016 for the American context). Our phrase here is meant to convey that the spaces exist on campus and are used to grow food.
}

2011, p. 103). Farms and gardens on post-secondary campuses "provide an alternative to the traditional model by focusing attention to sustainability initiatives and student leadership, as well as social dynamics such as food justice and community access to fresh produce" (Morris, 2017, p. 22). Classens and Burton (in press) demonstrate how campus food growing spaces constitute a paradigmatic pedagogical break from conventional agricultural education, while enabling students with the time and space to prefigure more equitable and ecologically rational food systems.

The notion of CFSA is informed by and builds on this work through a food systems lens. While work by Barlett (2011), Meek and Tarlau (2016), and Roberts-Stahlbrand (2020), and others demonstrate the learning opportunities of discrete spaces on campus-dining halls or campus farms-the CFSA analytic seeks to enable a broader focus in order to highlight the prefigurative and informal pedagogical value throughout the (alternative) campus food chain. In other words, we seek to theorize the moments all along the campus food system, from production through to disposal, as fundamentally pedagogical. Furthermore, by emphasizing the informal character of the learning opportunities afforded within CFSA, we seek to reveal how students are learning through the prefiguration and enactment of non-conventional food systems. Students have long been at the forefront of calls for socio-ecological change-from anti-apartheid politics, and the civil rights movement, through to fair trade and fossil fuel divestment policies (see Morgan and Davis, 2019). We see reflected within the context of CFSA glimmers of past and current student movements, as we seek to highlight and interrogate the pedagogy of these configurations.

An exhaustive qualitative and quantitative accounting of CFSA is beyond the scope of this short perspective piece, however we offer here a categorization schema that captures some of the diversity of these initiatives. It is worth noting that there is overlap between these categories, and the exemplars we feature here may express multiple dimensions within our schema.

To be sure, campus farm projects are the most common intervention, however our preliminary research reveals a rich diversity of allied initiatives that provide critical food systems learning opportunities along the food chain. As an example, the Seasoned Spoon Café at Trent University in Peterborough, Ontario, Canada is a co-operative café on campus that is run independent of the Chartwell's managed food system. The Seasoned Spoon provides paid and volunteer opportunities for students, they host a variety of food justice workshops and events, and importantly, they source over $50 \%$ of the food they sell in the café from a sister organization on campus - the Trent Vegetable Gardens. The remaining half of the food is sourced from local farmers or other co-ops in the area, demonstrating the contributions to sustainable local food systems CFSA make beyond the campus.

In some cases campus gardens provide food to culinary classes at their respective postsecondary institutions. For example, a portion of the food grown at the Humber College Food Learning Garden goes to The Humber Room-a student-run campus restaurant at Humber College. Similar partnerships take place with the Conestoga College Gardens and Conestoga's culinary 
classes as well as the Loyalist College Garden and the culinary program at Loyalist College.

\section{DISCUSSION AND CONCLUSION}

These examples, and others, gesture at the abundance of informal critical food systems learning occurring on campuses across Canada, and beyond. While we find some cases where opportunities within CFSA are deliberately integrated into course curricula, significant learning opportunities exist independent of formal programs. However, the character of many (critical) food systems programs provide fertile ground for supporting and encouraging greater formal integration of CFSA into course curricula. For example, Meek and Tarlau (2016, p. 238) observe that "at the university level, food system educators distinguish themselves from other pedagogical approaches by incorporating systems-thinking, group learning, and a direct connection between theory and practice." Furthermore, food systems courses and programs at post-secondary institutions are often "disruptive of common beliefs and practices about knowledge and learning" (Valley et al., 2017, p. 477). Experiential and service-learning opportunities within CFSA can expose students to the realpolitik of alternative food systems and student organizing, within the structure and support of a class. At the same time, the goal of faculty or programs ought not to be a full formalization of the informal learning within CFSA. Some degree of autonomy and student leadership are essential to the vibrancy and creativity of these initiatives-and researchers have much to learn about pedagogy of these spaces as they exist on their own terms. Building alliances, outside the classroom, with student-led campus food systems initiatives is one way of enacting Freirean praxis-of destabilizing the staid foundation of the educational orthodoxy toward the realization of more equitable and ecologically rational food systems.

Finally, it must be said that although our outlined approach to pedagogy may be unconventional in a colonial context, this is how many Indigenous peoples have always conceptualized education (Cajete, 1993; Anderson, 2002; Bell, 2013; Bell and Brant, 2015). Further, CFSA leaders are not automatically radical pedagogues by virtue of their surroundings: the type of work, whether it is fairly paid, what is grown, methods of distributions, and leadership and decision-making are all areas for conventional pedagogy to influence. Failure to acknowledge and actively work against this leaves CFSA collaborators vulnerable to reproducing white supremacist, colonial relationships in pedagogical spaces (Dei, 1996; Friedel, 2011; Tuck and Yang, 2012; Mclean, 2013; Tuck and McKenzie, 2015; Aikens et al., 2016; Lowan-Trudeau, 2017). If CFSA collaborators occupy and use land to achieve their ends without an interrogation of historical and ongoing land theft in Canada and of the University's position as "an essential part

\section{REFERENCES}

Aikens, K., McKenzie, M., and Vaughter, P. (2016). Environmental and sustainability educational policy research: A systematic review of of the colonizing process" (Smith, 1999, p. 65), they have doubly colonized the land that they operate on. This double-colonization is emblematic of the colonial state's project of ensuring settler futurity (Tuck and Gaztambide-Fernandez, 2013; Tuck et al., 2014), which also includes the repression of alternative food systems. Any form of education that does not explicitly centre the lived realities of Indigenous peoples, as well as Black and other racialized peoples, is a technology of settler colonialism and must be actively resisted.

CFSA that wish to embody radical pedagogy and resist settler colonialism must thoroughly examine their structures and processes. CFSA collaborators should center Black, Indigenous and racialized leadership and look for alternative methods of decision-making and distribution that rely on collectivity and mutuality. The lessons of Grundtvig, Carver, Du Bois and Washington echo in the work of (some) CFSA-but in order to realize the transformative potential of these spaces our radical pedagogy must be made explicit and deliberate (see for example Green, 2021).

Ultimately, in these fraught and uncertain times, we find hope and potential in CFSA. The students, staff and faculty committed to these initiatives are simultaneously forging more just and equitable food systems, while prefiguring new pedagogical paradigms. As we reckon with ongoing social inequity, global pandemics and climate chaos, Campus Food System Alternatives may serve as one crucible from which meaningful and lasting change emerges.

\section{DATA AVAILABILITY STATEMENT}

The raw data supporting the conclusions of this article will be made available by the authors, without undue reservation.

\section{ETHICS STATEMENT}

The project has been approved by the Trent University Research Ethics Board. The project follows the standards of the Canadian Tri-Council Research Ethics guidelines. The patients/participants provided their written informed consent to participate in this study.

\section{AUTHOR CONTRIBUTIONS}

All authors listed have made a substantial, direct, and intellectual contribution to the work and approved it for publication.

\section{FUNDING}

The authors would like to acknowledge Trent University for their generous financial support. 
Human Values. 37, 525-526. doi: 10.1007/s10460-020-10 043-7

Anderson, D. (2002). Preparing to teach our children the foundations of an Anishinaabe curriculum. McGill J. Educ. 37, 293-307.

Barlett, P. F. (2011). Campus sustainable food projects: Critique and engagement. Am. Anthropol. 113, 101-115. doi: 10.1111/j.1548-1433.2010.01 309.x

Battiste, M. (2013). Decolonizing Education: Nourishing the Learning Spirit. Saskatoon: Purich Publishing Limited.

Bell, N. (2013). Anishinaabe Bimaadiziwin: living spiritually with respect, relationship, reciprocity, and responsibility. In: Contemporary Studies in Environmental and Indigenous Pedagogies: A Curricula of Stories and Place, eds. Kulnieks, A., Longboat, D.R., and Young, K. (Rotterdam, Sense Publishers) p. 89-108. doi: 10.1007/978-94-6209-293-8_6

Bell, N., and Brant, T. (2015). Culturally Relevant Aboriginal Education: Teacher Education Series. Toronto: Pearson.

Buddel, N. (2015). Student affairs and services stream: college quarterly. College Q. 18, n1. Available online at: https://eric.ed.gov/?id=EJ1070130

Cajete, G. (1993). Look to the Mountain: An Ecology of Indigenous Education. Durango: Kivaki Press.

Carrier, S. (2009). The effects of outdoor science lessons with elementary school students on preservice teachers' self-efficacy. J. Element. Sci. Educ. 21, 35-48. doi: 10.1007/BF03173683

Chawla, L. (2015). Benefits of nature contact for children. J. Plan. Literat. 30, 433-452. doi: 10.1177/0885412215595441

Classens, M., and Burton, N. (in press). Prefigurative spaces of critical food literacy: the case for campus food growing spaces. In: Routledge Handbook for Sustainable Diets, Kevenay, K., and Prosperi, P. (eds) (London: Routledge), np.

Crouthers, S. D. (2021). Follow the pathway, follow the TRACKS: The impacts of community-based education on ESE and IK education implementation in the Greater Peterborough Area [Unpublished master's major research paper]. [Peterborough (ON)]: Trent University.

Cruz, A. R., Selby, S. T., and Durham, W. H. (2018). Place-based education for environmental behaviour: a 'funds of knowledge' and social capital approach. Environ. Educ. Res. 24, 627-647. doi: 10.1080/13504622.2017.1311842

Dei, G. (1996). Anti-Racism Education: Theory and Practice. Halifax: Fernwood Publishing.

Freire, P. (1968). Pedagogy of the Oppressed. New York: Bloomsbury.

Friedel, T. L. (2011). Looking for learning in all the wrong places: urban Native youths' cultured response to Western-oriented place-based learning. Int. J. Qualit. Stud. Educ. 24, 531-546. doi: 10.1080/09518398.2011.600266

Gannon, K. (2020). Radical Hope: A Teaching Manifesto. Morgantown: West Virginia Press.

Gonzalez, N., Moll, L., and Amanti, C. (2005). Funds of Knowledge: Theorizing Practices in Households, Communities and Classrooms. New York: Routledge.

Green, A. (2021). A new understanding and appreciation for the marvel of growing things: Exploring the college farm's contribution to transformative learning. Food, Cult. Soc. 3: 481-498. doi: 10.1080/15528014.2021.1883920

Holt-Gimenez, R., and Shattuck, A. (2011). Food crises, food regimes, and food movements: Rumblings of reform or tides of transformation? J. Peasant Stud. 38, 109-144. doi: 10.1080/03066150.2010.538578

Hooks, B. (1994). Teaching to transgress. Education as the practice of freedom. New York: Routledge.

Keeling, R. P. (2006). Learning Reconsidered 2: Implementing a campus-wide focus on the student experience. National Association of Student Personnel Administrators. Available online at: http://nirsa.net/nirsa/wp-content/uploads/ LearningReconsidered2.pdf. (accessed June 27, 2021).

LaCharite, K. (2016). Re-visioning agriculture in higher education: the role of campus agriculture initiatives in sustainability education. Agric. Human Values 33, 521-535. doi: 10.1007/s10460-015-9619-6

Lowan-Trudeau, G. (2017). Narrating a critical Indigenous pedagogy of place: a literary metissage. Educ. Theory. 67, 509-525. doi: 10.1111/edth. 12261
Mclean, S. (2013). The whiteness of green: Racialization and environmental education. Canad. Geograph. 57, 354-362. doi: 10.1111/cag.12025

Meek, D., and Tarlau, R. (2016). Critical food systems education (CFSE): educating for food sovereignty. Agroecol. Sustain. Food Syst. 40, 237-260. doi: 10.1080/21683565.2015.1130764

Mirwaldt, P. (2010). Health and wellness services. In: Achieving Student Success: Effective Students Services in Canadian Higher Education. ed. Cox, D.H., and Strange, C. (Montreal, QC; McGill-Queen's University Press) p. 89-99.

Moll, L. C. (2019). Elaborating funds of knowledge: community-oriented practices in international contexts. Liter. Res. Theor. Method Pract. 68, 130-138. doi: $10.1177 / 2381336919870805$

Morgan, D., and Davis, C.H.F. (2019). Student Activism, Politics, and Campus Climate in Higher Education. New York: Routledge. doi: $10.4324 / 9780429449178$

Morris, R. (2017). Farm Food Safety Plans: Customizing Educational Materials for Small-Scale and Campus-Based Farms. [Unpublished doctoral dissertation]. [Fort Collins, (CO)]: Colorado State University.

Roberts-Stahlbrand, A. (2020). Is the Meal Hall Part of the Campus Learning System? Investigating informal learning in a university residence meal hall. [Unpublished Master's thesis]. [Toronto (ON)]: Ontario Institute for Studies in Education, University of Toronto.

Sayre, L., and Clark, S. (2011). Fields of Learning: The Student Farm Movement in North America. Lexington, KY: University Press of Kentucky.

Smith, L. T. (1999). Decolonizing Methodologies: Research and Indigenous Peoples. London: Zed Books.

Tuck, E., and Gaztambide-Fernandez, R. A. (2013). Curriculum, replacement and settler futurity. J. Curric. Theoriz. 29, 72-89.

Tuck, E., and McKenzie, M. (2015). Relational validity and the "where" of inquiry: place and land in qualitative research. Qualit. Inquiry. 21, 633-638. doi: $10.1177 / 1077800414563809$

Tuck, E., McKenzie, M., and McCoy, K. (2014). Land education: Indigenous, postcolonial, and decolonizing perspectives on place and environmental education research. Environ. Educ. Res. 20, 1-23. doi: 10.1080/13504622.2013.877708

Tuck, E., and Yang, W. (2012). Decolonization is not a metaphor. Decoloniz. Indigen. Educ. Soc. 1, 1-40.

Valley, W., Wittman, H., Jordan, N., Ahmed, S., and Galt, R. (2017). An emerging signature pedagogy for sustainable food systems education. Renew. Agric. Food Syst. 33, 467-480. doi: 10.1017/S1742170517000199

Vetere, H. (2010). Housing and residence life. In: Achieving Student Success: Effective Students Services in Canadian Higher Education, eds. Cox, D.H., and Strange, C. (Montreal, QC; McGill-Queen's University Press) p. 77-88.

White, M. (2018). Freedom Farmers: Agricultural Resistance and the Black Freedom Movement. Chapel Hill: University of North Carolina Press. doi: 10.5149/northcarolina/9781469643694.001.0001

Conflict of Interest: The authors declare that the research was conducted in the absence of any commercial or financial relationships that could be construed as a potential conflict of interest.

Publisher's Note: All claims expressed in this article are solely those of the authors and do not necessarily represent those of their affiliated organizations, or those of the publisher, the editors and the reviewers. Any product that may be evaluated in this article, or claim that may be made by its manufacturer, is not guaranteed or endorsed by the publisher.

Copyright (C) 2021 Classens, Adam, Crouthers, Sheward and Lee. This is an openaccess article distributed under the terms of the Creative Commons Attribution License (CC BY). The use, distribution or reproduction in other forums is permitted, provided the original author(s) and the copyright owner(s) are credited and that the original publication in this journal is cited, in accordance with accepted academic practice. No use, distribution or reproduction is permitted which does not comply with these terms. 